\title{
Can erythrocytes release biologically active NO?
}

Peter M. Benz ${ }^{1,2^{*}}$ (D) and Ingrid Fleming ${ }^{1,2}$

\begin{abstract}
Under physiological conditions, endothelial cells and the endothelial nitric oxide (NO) synthase (eNOS) are the main source of $\mathrm{NO}$ in the cardiovascular system. However, several other cell types have also been implicated in the NO-dependent regulation of cell function, including erythrocytes. NO derived from red blood cells has been proposed to regulate erythrocyte membrane fluidity, inhibit platelet activation and induce vasodilation in hypoxic areas, but these proposals are highly controversial. In the current issue of Cell Communication and Signaling, an elegant study by Gambaryan et al., assayed NO production by erythrocytes by monitoring the activation of the platelet intracellular NO receptor, soluble guanylyl cyclase, and its downstream kinase protein kinase G. After systematically testing different combinations of erythrocyte/platelet suspensions, the authors found no evidence for platelet soluble guanylyl cyclase/protein kinase $\mathrm{G}$ activation by erythrocytes and conclude that erythrocytes do not release biologically active NO to inhibit platelet activation.
\end{abstract}

Keywords: Nitric oxide, NO, Red blood cells, Erythrocytes, eNOS, Platelet inhibition, Hypoxic vasodilation, VASP, Soluble guanylyl cyclase, PKG

\section{Commentary}

It is more than 20 years since nitric oxide (NO) was recognized as a biological signalling molecule in the cardiovascular system. NO is generated in endothelial cells by the constitutive endothelial nitric oxide synthase (eNOS), which converts L-arginine into $\mathrm{NO}$ and L-citrulline $[1,2]$. NO is a short-lived gaseous radical, which diffuses randomly to other cell types, including smooth muscle cells, platelets, and immune cells. Most, if not all, of the biological functions of $\mathrm{NO}$, including platelet inhibition and smooth muscle relaxation, are mediated by the soluble guanylate cyclase (sGC), which converts GTP to cGMP and thereby activates the protein kinase G (PKG) [3-5] (Fig. 1). The activity of eNOS is largely dependent on an increase in the intracellular concentration of calcium $\left[\mathrm{Ca}^{2+}\right]_{\mathrm{i}}$, released from the endoplasmic reticulum in response to the activation of receptordependent ligands such as acetylcholine, bradykinin, or histamine. eNOS can also be activated, in the absence of a prolonged increase in $\left[\mathrm{Ca}^{2+}\right]_{\mathrm{i}}$ by stimuli that elicit

\footnotetext{
* Correspondence: benz@vrc.uni-frankfurt.de

${ }^{1}$ Institute for Vascular Signalling, Centre for Molecular Medicine, Johann Wolfgang Goethe University, Frankfurt, Germany

${ }^{2}$ DZHK (German Centre for Cardiovascular Research) partner site Rhine-Main, 60590 Frankfurt am Main, Germany
}

(c) 2016 The Author(s). Open Access This article is distributed under the terms of the Creative Commons Attribution 4.0 International License (http://creativecommons.org/licenses/by/4.0/, which permits unrestricted use, distribution, and reproduction in any medium, provided you give appropriate credit to the original author(s) and the source, provide a link to the Creative Commons license, and indicate if changes were made. The Creative Commons Public Domain Dedication waiver (http://creativecommons.org/publicdomain/zero/1.0/) applies to the data made available in this article, unless otherwise stated.

the phosphorylation of eNOS on Ser1177. One such stimulus is the fluid shear stress that acts on the luminal surface of vascular endothelium $[1,2]$ (Fig. 1). In addition to endothelial cells, several other cell types have been reported to generate and release NO; these include vascular smooth muscle cells and cardiac muscle cells. Even though they contain large amounts of the NO scavenger hemoglobin, red blood cells (RBCs, erythrocytes) have also been reported to express eNOS [6] and generate/release NO [7-9] but these observations are still highly controversial.

Erythrocytes and platelets represent the major cell populations in the mammalian blood and clinical observations indicate a functional interaction between the two cell types. On the one hand, there is an undisputed role of erythrocytes in platelet activation as bleeding times are prolonged in patients with anemia independent of their platelet count - a condition that can be corrected by erythrocyte transfusion $[10,11]$. Importantly, the bleeding defects observed are directly associated with an impaired platelet activation and independent of the blood coagulation system [12]. Furthermore, erythrocyte transfusion can increase platelet activation, which may result in complications in treatment of coronary 


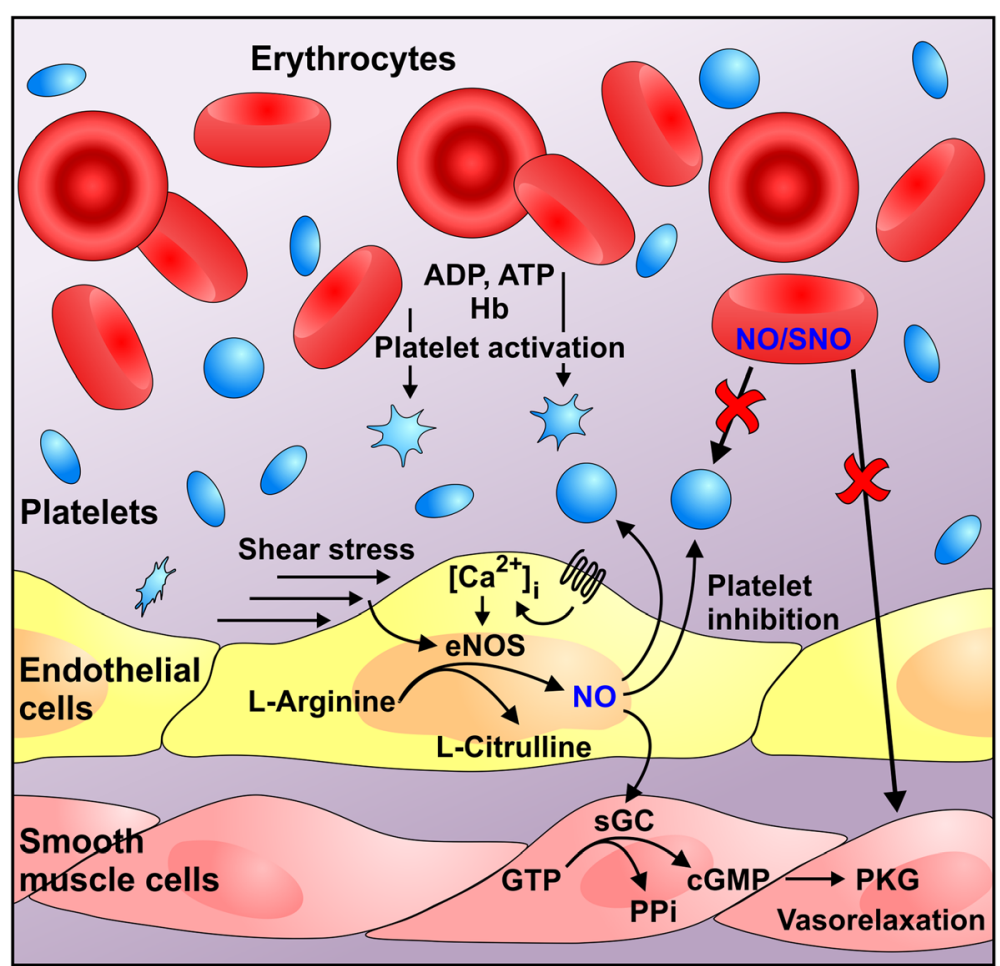

Fig. 1 Role of nitic oxide (NO) in blood vessels and functional interplay between erythrocytes and platelets. NO is generated by the endothelial NO synthase (eNOS) upon stimulation by fluid shear stress or $\mathrm{Ca}^{2+}$ elevating agonists. The biological actions of NO, including platelet inhibition and smooth muscle relaxation, are mediated by the soluble guanylate cyclase (sGC), which generates $\mathrm{CGMP}$ and the subsequent activation of protein kinase G (PKG). Erythrocytes play a role in the regulation of platelet activation as ADP and ATP secreted from damaged erythrocytes directly stimulates platelet purinergic receptors ( $\mathrm{P}_{2} \mathrm{Y}_{12}, \mathrm{P}_{2} \mathrm{Y}_{1}$, and $\left.\mathrm{P}_{2} \mathrm{X}_{1}\right)$. Secreted hemoglobin ( $\mathrm{Hb}$ ) scavenges endothelial-derived $\mathrm{NO}$ and therefore decreases platelet inhibition. It has been proposed that erythrocytes also play a role in platelet inhibition by generation/release of NO or NO-carriers, such as SNO. While it is still debatable whether or not erythrocytes can generate NO/SNO, current experimental evidence by Gambaryan et al. concludes that erythrocytes do not release biologically active NO/SNO

artery diseases [13]. How erythrocytes contribute to platelet activation is still under debate, but this may involve activation of the ADP-P2Y $\mathrm{Y}_{12}$ receptor pathway and/or the elevated platelet radial movement and interaction with the endothelium $[10,12]$.

Several recent studies have indicated a role for erythrocytes in platelet inhibition by virtue of their ability to release NO [7-9]. Three contradictory mechanisms have been proposed by which erythrocytes may provide NO. The first suggestion was that the nitrosation of a conserved cysteine within the hemoglobin $(\mathrm{Hb}) \beta$-chain ( $\beta 93$ cysteine) by $\mathrm{NO}$ results in the formation of S-nitrosohemoglobin (SNO-Hb), which could function as an NO carrier [14]. The second proposal was that deoxyhemoglobin (deoxy$\mathrm{Hb}$ ) may act as a nitrite reductase, and catalyze the formation of NO (and methemoglobin) from inorganic nitrite [15-17]. The third hypothesis is that NO derived from eNOS protein expressed in erythrocytes may directly inhibit platelet aggregation [6]. All of these hypotheses have been the subject of intense debate and all have been challenged by other authors. For example, the generation of a knockin mouse model that replaced hemoglobin $\beta$ cysteine93 with alanine helped to conclude that $\mathrm{SNO}-\mathrm{Hb}$ is not essential for the coupling of erythrocyte deoxygenation with increased NO bioactivity in vivo [18]. Moreover, detailed electron paramagnetic resonance (EPR) spectroscopy of nitrite-methemoglobin complexes questioned the proposed role of deoxyhemoglobin in generating NO by the reduction of nitrite [19]. Finally, other authors failed to detect a functional eNOS in erythrocytes [20].

General doubt about the release of NO or NO-carriers from erythrocytes comes from the fact that $\mathrm{Hb}$ is an avid scavenger of NO. Notably, physiological NO concentrations range between $100 \mathrm{pM}$ (or below) up to $\sim 5 \mathrm{nM}$, at least six orders of magnitude below the $\mathrm{Hb}$ concentration in erythrocytes [21]. Thus while the erythrocyte membrane and the cell free zone established in resistance-sized arteries can reduce the apparent rate at which endotheliumderived $\mathrm{NO}$ is consumed by $\mathrm{Hb}[22,23]$, the situation is dramatically different inside red blood cells. As outlined above, most of the biological actions of NO, including platelet inhibition and smooth muscle relaxation, are mediated by the sGC/cGMP/PKG pathway (Fig. 1). An 
important limitation of all of the publications, which claimed platelet inhibition by erythrocyte-derived NO, is that direct activation of the sGC/cGMP/PKG pathway in platelets was not investigated. Together with the conflicting experimental results described above, the ongoing debate about generation and release of $\mathrm{NO}$ (or NO carriers) from erythrocytes has precluded a consensus on the physiological role of erythrocytes in platelet inhibition.

In the current issue of Cell Communication and Signaling, Gambaryan et al. [24] set out to solve the discrepancy regarding erythrocyte-mediated platelet inhibition by asking a very simple and logical question. If erythrocytes indeed release physiological relevant levels of NO or SNO to inhibit platelet activation, then the sGC/cGMP/PKG pathway in platelets should be activated, irrespective of the mechanism by which $\mathrm{NO} / \mathrm{SNO}$ are generated in red blood cells. The authors monitored the effects of NO in platelets by assessing the activity of purified sGC in the presence of erythrocytes as well as the $\mathrm{NO} / \mathrm{sGC} / \mathrm{cGMP} /$ PKG-dependent phosphorylation of vasodilator-stimulated phosphoprotein (VASP). The latter is a highly sensitive and reliable assay, used in numerous studies to assess NO-dependent effects and which is widely used in clinical diagnosis of platelet reactivity [25-29]. Other assays that aim to assess the role of $\mathrm{NO}$ in platelets, e.g. by the ELISA-base measurement of cGMP, seem to be prone to artefacts, especially in the presence of nitrite or erythrocytes, which both interfere with these assays [30]. Gambaryan et al. systematically tested all possible combinations of erythrocyte/platelet suspensions over time, with varying erythrocyte concentrations, as well as studying erythrocytes containing $\mathrm{Hb}$ in different states (oxy-Hb, deoxy-Hb, NO-Hb), with or without nitrite, and platelets isolated under normal or deoxygenated conditions [24]. They found no evidence of platelet and purified sGC activation by erythrocytes. Instead, the authors discovered a strong scavenging effect of NO by erythrocytes - even if NO was added exogenously. Consequently, the authors came to the conclusion that erythrocytes, under all of the conditions tested, cannot inhibit platelet activation by the release of physiological active NO, but in strong contrast act as potent NO scavengers.

At least one additional physiological function has been attributed to erythrocyte-derived NO i.e., the phenomenon of hypoxic vasodilation. According to a hypothesis put forward several years ago [31], erythrocytes have an essential role in matching blood flow to local metabolic demand that can be explained by $\mathrm{NO}$ release from $\mathrm{Hb}$ at low oxygen saturation of blood $\mathrm{Hb}$ to elicit vasodilatation $[31,32]$. To-date it is unclear what form this NO has to take to avoid efficient scavenging by oxygen bound to the heme of oxyhemoglobin or with the unoccupied heme of deoxyhemoglobin [33], but NO release form $\mathrm{RBCs}$ has been proposed to occur via the reduction of nitrite, the SNO-hemoglobin pathway, as well as endogenous erythrocyte eNOS activity [34]. Even though no contribution to hypoxic vasodilatation was specifically studied, Gambaryan et al. [24] found no evidence for $\mathrm{NO} / \mathrm{SNO}$ release form $\mathrm{RBCs}$ in erythrocyte/platelet suspensions using the sensitive platelet sGC/cGMP/ PKG pathway as NO sensor. Given that activation of the same pathway in smooth muscle cells would be mandatory for NO-dependent hypoxic vasodilation, it seems very unlikely that any $\mathrm{RBC}$-derived $\mathrm{NO} / \mathrm{SNO}$ could diffuse to the much more distant smooth muscle cells.

\section{Conclusions}

In summary, it is still debatable whether or not erythrocytes possess the functional machinery to generate $\mathrm{NO} / \mathrm{SNO}$. However, irrespective of this question, the study by Gambaryan et al. [24] seems to resolve some of the current controversy by concluding that erythrocytes do not release biologically active NO.

\section{Abbreviations \\ CGMP: Cyclic guanosine monophosphate; eNOS: Endothelial NO synthase; EPR: Electron paramagnetic resonance; NO: Nitric oxide; PKG: Protein kinase G; RBCs: Red blood cells; sGC: Soluble guanylyl cyclase; \\ SNO-Hb: S-nitrosohemoglobin; VASP: Vasodilator-stimulated phosphoprotein \\ Acknowledgements \\ Not applicable. \\ Funding \\ PMB and IF were supported by grants from the Deutsche Forschungsgemeinschaft (grant SFB834, projects A8 and A9) and the German Center for Cardiovascular Research (DZHK).}

\section{Availability of data and materials \\ Not applicable.}

\section{Authors' contributions}

PMB and IF wrote the paper and approved the final manuscript.

\section{Competing interests}

The authors declare that they have no competing interests.

Consent for publication

Not applicable.

Ethics approval and consent to participate

Not applicable.

Received: 7 September 2016 Accepted: 13 September 2016 Published online: 17 September 2016

References

1. Fleming I. Molecular mechanisms underlying the activation of eNOS. Pflugers Arch. 2010;459:793-806.

2. Siragusa M, Fleming I. The eNOS signalosome and its link to endothelial dysfunction. Pflugers Arch. 2016;468:1125-37.

3. Koesling D, Friebe A. Soluble guanylyl cyclase: structure and regulation. Rev Physiol Biochem Pharmacol. 1999;135:41-65.

4. Martin E, Berka V, Tsai AL, Murad F. Soluble guanylyl cyclase: the nitric oxide receptor. Methods Enzymol. 2005;396:478-92.

5. Tsai AL, Berka V, Sharina I, Martin E. Dynamic ligand exchange in soluble guanylyl cyclase (sGC): implications for sGC regulation and desensitization. J Biol Chem. 2011;286:43182-92. 
6. Cortese-Krott MM, Rodriguez-Mateos A, Sansone R, Kuhnle GG, Thasian-Sivarajah S, Krenz T, Horn P, Krisp C, Wolters D, Heiss C, et al. Human red blood cells at work: identification and visualization of erythrocytic eNOS activity in health and disease. Blood. 2012;120:4229-37.

7. Srihirun S, Sriwantana T, Unchern S, Kittikool D, Noulsri E, Pattanapanyasat K, Fucharoen S, Piknova B, Schechter AN, Sibmooh N. Platelet inhibition by nitrite is dependent on erythrocytes and deoxygenation. PLoS One. 2012;7:e30380.

8. Corti P, Xue J, Tejero J, Wajih N, Sun M, Stolz DB, Tsang M, Kim-Shapiro DB, Gladwin MT. Globin X is a six-coordinate globin that reduces nitrite to nitric oxide in fish red blood cells. Proc Natl Acad Sci U S A. 2016;113:8538-43.

9. Akrawinthawong K, Park JW, Piknova B, Sibmooh N, Fucharoen S, Schechter AN. A flow cytometric analysis of the inhibition of platelet reactivity due to nitrite reduction by deoxygenated erythrocytes. PLoS One. 2014;9:e92435.

10. Anand A, Feffer SE. Hematocrit and bleeding time: an update. South Med J. 1994:87:299-301.

11. Boneu B, Fernandez F. The role of the hematocrit in bleeding. Transfus Med Rev. 1987:1:182-5.

12. Silvain J, Abtan J, Kerneis M, Martin R, Finzi J, Vignalou JB, Barthelemy O, O'Connor SA, Luyt CE, Brechot N, et al. Impact of red blood cell transfusion on platelet aggregation and inflammatory response in anemic coronary and noncoronary patients: the TRANSFUSION-2 study (impact of transfusion of red blood cell on platelet activation and aggregation studied with flow cytometry use and light transmission aggregometry). J Am Coll Cardiol. 2014;63:1289-96

13. Kumbhani DJ, Bhatt DL. Platelet activation: yet another strike against routine TRANSFUSION. Eur Heart J. 2010:31:2712-4.

14. Jia L, Bonaventura C, Bonaventura J, Stamler JS. S-nitrosohaemoglobin: a dynamic activity of blood involved in vascular control. Nature. 1996;380:221-6.

15. Tejero J, Basu S, Helms C, Hogg N, King SB, Kim-Shapiro DB, Gladwin MT. Low NO concentration dependence of reductive nitrosylation reaction of hemoglobin. J Biol Chem. 2012;287:18262-74.

16. Basu S, Grubina R, Huang J, Conradie J, Huang Z, Jeffers A, Jiang A, He X, Azarov I, Seibert R, et al. Catalytic generation of N2O3 by the concerted nitrite reductase and anhydrase activity of hemoglobin. Nat Chem Biol. 2007:3:785-94

17. Cosby K, Partovi KS, Crawford JH, Patel RP, Reiter CD, Martyr S, Yang BK, Waclawiw MA, Zalos G, Xu X, et al. Nitrite reduction to nitric oxide by deoxyhemoglobin vasodilates the human circulation. Nat Med. 2003;9:1498-505.

18. Isbell TS, Sun CW, Wu LC, Teng X, Vitturi DA, Branch BG, Kevil CG, Peng N, Wyss JM, Ambalavanan N, et al. SNO-hemoglobin is not essential for red blood cell-dependent hypoxic vasodilation. Nat Med. 2008;14:773-7.

19. Schwab DE, Stamler JS, Singel DJ. Nitrite-methemoglobin inadequate for hypoxic vasodilation. Nat Chem Biol. 2009;5:366. author reply 367.

20. Bohmer A, Beckmann B, Sandmann J, Tsikas D. Doubts concerning functional endothelial nitric oxide synthase in human erythrocytes. Blood. 2012;119:1322-3.

21. Hall CN, Garthwaite J. What is the real physiological NO concentration in vivo? Nitric Oxide. 2009;21:92-103.

22. Azarov I, Huang KT, Basu S, Gladwin MT, Hogg N, Kim-Shapiro DB. Nitric oxide scavenging by red blood cells as a function of hematocrit and oxygenation. J Biol Chem. 2005;280:39024-32.

23. Azarov I, Liu C, Reynolds H, Tsekouras Z, Lee JS, Gladwin MT, Kim-Shapiro DB. Mechanisms of slower nitric oxide uptake by red blood cells and other hemoglobin-containing vesicles. J Biol Chem. 2011;286:33567-79.

24. Gambaryan S, Subramanian H, Kehrer L, Mindukshev I, Sudnitsyna J, Reiss C, Rukoyatkina N, Friebe A, Sharina I, Martin E, Walter U. Erythrocytes do not activate purified and platelet soluble guanylate cyclases even in conditions favourable for NO synthesis. Cell Commun Signal. 2016;14:16.

25. Munzel T, Feil R, Mulsch A, Lohmann SM, Hofmann F, Walter U. Physiology and pathophysiology of vascular signaling controlled by guanosine 3',5'-cyclic monophosphate-dependent protein kinase [corrected]. Circulation. 2003;108:2172-83.

26. Bonello L, Camoin-Jau L, Arques S, Boyer C, Panagides D, Wittenberg O, Simeoni MC, Barragan P, Dignat-George F, Paganelli F. Adjusted clopidogrel loading doses according to vasodilator-stimulated phosphoprotein phosphorylation index decrease rate of major adverse cardiovascular events in patients with clopidogrel resistance: a multicenter randomized prospective study. J Am Coll Cardiol. 2008;51:1404-11.

27. Bonello L, Paganelli F, Arpin-Bornet M, Auquier P, Sampol J, Dignat-George F, Barragan P, Camoin-Jau L. Vasodilator-stimulated phosphoprotein phosphorylation analysis prior to percutaneous coronary intervention for exclusion of postprocedural major adverse cardiovascular events. J Thromb Haemost. 2007;5:1630-6.

28. Schwarz UR, Geiger J, Walter U, Eigenthaler M. Flow cytometry analysis of intracellular VASP phosphorylation for the assessment of activating and inhibitory signal transduction pathways in human platelets-definition and detection of ticlopidine/clopidogrel effects. Thromb Haemost. 1999;82:1145-52.

29. Walter U, Gambaryan S. CGMP and cGMP-dependent protein kinase in platelets and blood cells. Handb Exp Pharmacol. 2009;191:533-48.

30. Gambaryan S, Tsikas D. A review and discussion of platelet nitric oxide and nitric oxide synthase: do blood platelets produce nitric oxide from L-arginine or nitrite? Amino Acids. 2015;47:1779-93.

31. Singel DJ, Stamler JS. Chemical physiology of blood flow regulation by red blood cells: the role of nitric oxide and S-nitrosohemoglobin. Annu Rev Physiol. 2005;67:99-145.

32. Diesen DL, Hess DT, Stamler JS. Hypoxic vasodilation by red blood cells: evidence for an s-nitrosothiol-based signal. Circ Res. 2008;103:545-53.

33. Robinson JM, Lancaster Jr JR. Hemoglobin-mediated, hypoxia-induced vasodilation via nitric oxide: mechanism(s) and physiologic versus pathophysiologic relevance. Am J Respir Cell Mol Biol. 2005;32:257-61.

34. Kulandavelu S, Balkan W, Hare JM. Regulation of oxygen delivery to the body via hypoxic vasodilation. Proc Natl Acad Sci U S A. 2015;112:6254-5.

\section{Submit your next manuscript to BioMed Central and we will help you at every step:}

- We accept pre-submission inquiries

- Our selector tool helps you to find the most relevant journal

- We provide round the clock customer support

- Convenient online submission

- Thorough peer review

- Inclusion in PubMed and all major indexing services

- Maximum visibility for your research

Submit your manuscript at www.biomedcentral.com/submit

) Biomed Central 